here were comparable,,$^{3-5}$ with the exception of acebutolol, which was probably underestimated by some $25-50 \%{ }^{6}$

Owing to the design of this trial the effect of dose increments cannot be differentiated from a further period of exposure to the drugs, and this must be borne in mind when comparing the results. There was little to choose between atenolol and propranolol during the low-dose period, although in higher dosage atenolol was significantly better than all other drugs.

Pindolol proved disappointing in both its lack of hypotensive effectiveness and its high side-effect score, which might limit the use of higher doses. In an open study, however, Sedgwick and Crowder ${ }^{7}$ reported a low incidence of side effects with doses of 5-15 mg given three times a day. Wilson et al, ${ }^{8}$ who studied five patients, found that an average of $29 \mathrm{mg}$ given once daily was as effective as the same amount given in divided doses. Two of their patients reported insomnia, which was abolished by taking the drug in the morning rather than at night. Pindolol has considerable intrinsic sympathomimetic activity, which was reflected in the high resting pulse rate recorded in my study.

My findings suggest that the theoretically useful combination of alpha-blockade and beta-blockade possessed by labetalol will not be competitive as a once-daily treatment. This is unfortunate, for we still lack a good peripheral vasodilator that acts for at least 24 hours and could complement a once-daily regimen of a beta-blocker with or without a diuretic. Labetalol also caused as many side effects as pindolol, both having nearly twice the side-effect score of the other drugs.

The reduction of exercise-induced peaks of blood pressure and heart rate is commonly cited as a major advantage of betablockers, but we do not know whether such peaks carry important risks. None of the drugs used here totally prevented significant increases in either heart rate or systolic blood pressure with exercise. Although the measurements were made at least
24 hours after the last dose of tablets, they raise the question whether it will ever be possible to inhibit such increments in blood pressure or heart rate for the whole 24-hour period after a single daily dose of a beta-blocker; and if not would it matter ?

The hypotensive potential of bendrofluazide as a once-daily treatment compared with some of the beta-blockers was confirmed, and this drug is likely to remain an important contender as a first-line choice for mild and moderate essential hypertension, particularly in countries with limited budgets, since the beta-blockers are all much more expensive. The hypokalaemic and hyperuricaemic effects of bendrofluazide are rarely important.

I thank Professor J R A Mitchell for constructive criticism of this paper, the department of clinical chemistry, Nottingham General Hospital, for the biochemical estimations, and Miss Jayne Patrick for typing the manuscript.

\section{References \\ ${ }^{1}$ Douglas-Jones, A P, and Cruickshank, J M, British Medical fournal, 1976 , 1,990 \\ 2 Castleden, C M, Dathan, J R E, and George, C F, Postgraduate Medical Fournal, 1977, 53, 679. \\ ${ }^{3}$ Conway, F J, et al, British fournal of Clinical Pharmacology, 1976, 3, 267 \\ ${ }^{4}$ Richards, D A, British fournal of Clinical Pharmacology, 1976, 3, suppl No 3, p 721 . \\ ${ }^{5}$ Bühler, F R, et al, Clinical Science and Molecular Medicine, 1975, 48, 61. \\ ${ }^{6}$ Lewis, B S, et al, British Heart Fournal, 1973, 35, 743. \\ 7 Sedgwick, J P, and Crowder, D, Current Medical Research and Opinion, 1975, 3, 89. \\ ${ }^{8}$ Wilson, M, Morgan, G, and Morgan, T, British Fournal of Clinical Pharmacology, 1976, 3, 857.}

\title{
Need for beta-blockade in hypertension reduced with long-term minoxidil
}

\author{
HANS R BRUNNER，PHILLIPPE JAEGER， ROGER K FERGUSON， ERIC JEQUIER, \\ GUSTAVE TURINI, HARALAMBOS GAVRAS
}

British Medical fournal, 1978, 2, 385-388

\section{Summary and conclusions}

Sequential changes in plasma renin activity and urinary aldosterone and noradrenaline were assessed in eight patients with severe hypertension after minoxidil had been added to their treatment. Doses of 2.5-27.5 (mean 12.5) $\mathrm{mg} /$ day reduced the mean blood pressure from $166 / 1136 / 2 \mathrm{~mm} \mathrm{Hg}$ to $124 / 884 / 2 \mathrm{~mm} \mathrm{Hg}$ in one week. Plasma renin activity and urinary aldosterone and noradrenaline increased twofold to threefold initially but returned to baseline values within two to three weeks

Department of Medicine, Centre Hospitalier Universitaire, Lausanne, Switzerland

HANS R BRUNNER, MD, associate professor of medicine

PHILIPPE JAEGER, MD, research fellow

ROGER K FERGUSON, MD, professor of pharmacology and medicine

ERIC JEQUIER, MD, professor of physiology

GUSTAVE TURINI, MD, research associate

HARALAMBOS GAVRAS, MD, associate professor of medicine and remained unchanged during a mean follow-up of $5 \cdot 1$ months. Beta-blocking drugs were then withdrawn slowly in six patients without adverse effects, though blood pressure and heart rate increased in three patients, who required minimal doses of beta-blockers. Plasma renin activity and urinary aldosterone and noradrenaline did not change significantly after beta-blockade had been stopped. We conclude that the need for betablockade is greatly reduced with long-term minoxidil treatment and that it may be unnecessary in some patients.

\section{Introduction}

Minoxidil ${ }^{1}$ used in combination with beta-blocking agents has proved useful for treating hypertension resistant to other drugs. ${ }^{2}$ It was more powerful than hydrallazine in patients already treated with diuretics and propranolol, ${ }^{3}$ and was particularly useful in patients with hypertension and renal failure. ${ }^{4}$ In most studies minoxidil increased plasma renin activity ${ }^{12}{ }^{5}$-an effect that occurs with other vasodilator drugs. ${ }^{6}{ }^{7}$ These drugs also stimulate the secretion of catecholamines, which may oppose their antihypertensive effect ${ }^{15}$ and explain why giving minoxidil without concomitant beta-blockade was unsuccessful. ${ }^{1}$ 
Clinical characteristics of patients

\begin{tabular}{|c|c|c|c|c|c|c|c|c|}
\hline $\begin{array}{l}\text { Case } \\
\text { No }\end{array}$ & $\begin{array}{c}\text { Age } \\
\text { (years) }\end{array}$ & Sex & Diagnosis & $\begin{array}{c}\text { Duration of } \\
\text { hypertension } \\
\text { (years) }\end{array}$ & $\begin{array}{l}\text { Fundal } \\
\text { grade }\end{array}$ & $\begin{array}{l}\text { Last treatment } \\
\text { before study* } \\
\text { (mg/day) }\end{array}$ & $\begin{array}{l}\text { Last sitting } \\
\text { blood pressure } \\
(\mathrm{mm} \mathrm{Hg})\end{array}$ & $\begin{array}{c}\text { Serum } \\
\text { creatinine } \\
(\mu \mathrm{mol} / 1)\end{array}$ \\
\hline $\begin{array}{l}1 \\
2 \\
3 \\
4 \\
5 \\
6 \\
7 \\
8\end{array}$ & $\begin{array}{l}48 \\
27 \\
48 \\
47 \\
45 \\
42 \\
47 \\
35\end{array}$ & $\begin{array}{l}\mathrm{F} \\
\mathrm{M} \\
\mathrm{M} \\
\mathrm{M} \\
\mathrm{F} \\
\mathrm{M} \\
\mathrm{M} \\
\mathrm{M}\end{array}$ & $\begin{array}{l}\text { Essential hypertension } \\
\text { Essential hypertension } \\
\text { Essential hypertension } \\
\text { Essential hypertension } \\
\text { Essential hypertension } \\
\text { Essential hypertension } \\
\text { Essential hypertension } \\
\text { Chronic glomerulonephritis; } \\
\text { renal transplantation }\end{array}$ & $\begin{array}{r}1 \\
1 \\
9 \\
4 \\
7 \\
21 \\
9 \\
6\end{array}$ & $\begin{array}{l}\text { I } \\
\text { I-II } \\
\text { I } \\
\text { II } \\
\text { II } \\
\text { II } \\
\text { I-II } \\
\text { I }\end{array}$ & $\begin{array}{l}\text { C } 100 ; \mathrm{S} 100 ; \mathrm{P} 320 ; \mathrm{H} 100 \\
\text { C } 100 ; \mathrm{S} 100 ; \mathrm{P} 320 ; \mathrm{H} 100 \\
\text { C } 100 ; \mathrm{S} 100 ; \mathrm{P} 240 ; \mathrm{H} 100 \\
\text { C } 100 ; \mathrm{S} 100 ; \mathrm{O} 320 ; \mathrm{H} 100 \\
\text { C } 100 ; \mathrm{S} 100 ; \mathrm{O} 320 ; \mathrm{H} 100 \\
\text { C } 100 ; \mathrm{S} 100 ; \mathrm{P} 320 ; \mathrm{H} 100 \\
\text { C } 100 ; \mathrm{P} 240 ; \mathrm{H} 100 \\
\text { C } 100 ; \mathrm{S} 100 ; \mathrm{MD} 2000 ; \mathrm{H} 100\end{array}$ & $\begin{array}{l}150 / 105 \\
157 / 108 \\
153 / 105 \\
165 / 105 \\
158 / 108 \\
140 / 113 \\
170 / 105 \\
180 / 115\end{array}$ & $\begin{array}{r}88 \cdot 4 \\
168 \cdot 0 \\
123 \cdot 8 \\
238 \cdot 7 \\
97 \cdot 2 \\
115 \cdot 0 \\
97 \cdot 2 \\
203 \cdot 3\end{array}$ \\
\hline
\end{tabular}

${ }^{*} \mathrm{C}=$ Chlorthalidone. $\mathrm{S}=$ Spironolactone. $\mathrm{P}=$ Propranolol. $\quad \mathrm{O}=$ Oxprenolol. $\quad \mathrm{H}=$ Dihydrallazine. $\quad \mathrm{MD}=$ Methyldopa.

Conversion: SI to traditional units-Serum creatinine: $1 \mu \mathrm{mol} / 1 \approx 0.01 \mathrm{mg} / 100 \mathrm{ml}$.

We decided to assess the long-term sequential changes in plasma renin activity, aldosterone, and catecholamines in hypertensive patients after substituting minoxidil for dihydrallazine, and to determine the need for continuous betablockade.

\section{Patients and methods}

Six men and two women aged 27-48 years were studied. All had had severe hypertension for 1-21 (mean 7) years. In seven essential hypertension was diagnosed on the basis of a compatible history and physical findings, routine laboratory evaluation, a rapid-sequence pyelogram, and (in four) renal arteriograms. One man had undergone renal transplantation one year before for chronic glomerulonephritis, and another had associated hypogonadism of unknown aetiology. Fundi were graded I-II according to the Keith-Wagener classification. Initial serum creatinine averaged $141 \pm \mathrm{SE}$ of mean $19.4 \mu \mathrm{mol} / \mathrm{l}$ $(1.6 \pm 0.22 \mathrm{mg} / 100 \mathrm{ml})$. All patients had received a combination of three or four antihypertensive agents (table), yet sitting blood pressure consistently exceeded $140 \mathrm{~mm} \mathrm{Hg}$ systolic and $100 \mathrm{~mm} \mathrm{Hg}$ diastolic (mean 159/108 $\pm 4 \cdot 4 / 1.4 \mathrm{~mm} \mathrm{Hg}$ ). Each patient gave informed consent for treatment with minoxidil.

Ten days before admission dihydrallazine was discontinued; other antihypertensive drugs were unchanged. During the first three days in hospital blood pressure was stabilised and two full baseline measurements were made. On the fourth morning minoxidil, $2.5 \mathrm{mg}$ by mouth, was begun. Each day thereafter 2.5-5.0 mg was added in divided doses until the diastolic pressure fell below $90 \mathrm{~mm} \mathrm{Hg}$ or side effects occurred. The dose necessary to accomplish satisfactory reduction ranged from 2.5 to 27.5 (mean 12.5 ) $\mathrm{mg} /$ day. Each patient received a diet containing $100 \mathrm{mmol}(\mathrm{mEq})$ sodium daily.

After 10 days in hospital patients were followed up in the outpatient department, at first weekly and then every four weeks if free of symptoms. They were seen by the same physician and at the same time of day. They were advised to restrict salt intake. At the end of phase 1-that is, after 1-9 (mean 5.1) months-sodium intake was again restricted to about $100 \mathrm{mmol} /$ day to duplicate baseline conditions.

In phase 2 the dose of beta-blocking drugs was halved every month in six patients and when it had reached $40 \mathrm{mg}$ daily they were stopped. Patients were then followed up for another 4-9 (mean 6.2) months, and three were again given small doses of propranolol (less than $40 \mathrm{mg} /$ day).

Certain modifications to treatment were necessary after minoxidil was started. Minor adjustments in the dose of minoxidil were made in two cases after discharge for better control of blood pressure or because of side effects. Weight gain due to sodium retention necessitated intermittent or continuous frusemide in four patients (see Results). The dose of spironolactone had to be halved in two patients because of gynaecomastia, without compensation by another drug.

In hospital blood pressure, heart rate, body weight, plasma renin activity, and 24-hour urinary excretion of sodium, potassium, creatinine, noradrenaline, adrenaline, and aldosterone were measured daily. After discharge sitting blood pressure, heart rate, and weight were determined at each visit and plasma and urine measurements repeated. We specifically looked for side effects.

Blood samples for analysis of renin activity were chilled and immediately centrifuged in the cold; plasma was separated and frozen at $-30^{\circ} \mathrm{C}$. Renin activity was analysed by angiotensin I radioimmunoassay. ${ }^{8}$ Urinary aldosterone was quantified by radioimmunoassay, ${ }^{9}$ and urinary catecholamines were determined by a fluorometric method. ${ }^{10}$ Electrolytes and creatinine concentrations were measured in the central hospital laboratory.

Statistical comparisons between groups were performed with Student's $t$ test for paired data.

\section{Results}

PHASE 1

No major adverse effects occurred during the introduction of minoxidil. One patient withdrew from the study early because of non-specific side effects, and another, the man with hypogonadism, $G$ died suddenly in another country; necropsy was not performed and the cause of death was not ascertained.

After dihydrallazine had been stopped the average blood pressure in the eight patients increased from $150 / 108 \pm 4 \cdot 4 / 1 \cdot 4$ to $166 / 113 \pm 5 \cdot 7 / 2 \cdot 4$ $\mathrm{mm} \mathrm{Hg}$. One week after they started minoxidil it was $124 / 88 \pm 4 \cdot 2 / 1.9$ $\mathrm{mm} \mathrm{Hg}$. After discharge the mean arterial pressure rose slightly in the six patients completing the trial (fig 1). This was ascribed to sodium retention due to minoxidil and relaxation of the dietary sodium restriction. Body weight increased by an average of $1 \mathrm{~kg}$ and frusemide, $40-80 \mathrm{mg} /$ day, was therefore given by mouth to four patients with a resultant fall in pressure. By the end of phase 1 the mean arterial pressure was $99 \pm 2.4 \mathrm{~mm} \mathrm{Hg}$ and body weight $79 \pm 5.2 \mathrm{~kg}$. Heart rate changed little, averaging $69 \pm 4$ and $75 \pm 6$ beats/min on days 1 and 8 of minoxidil administration respectively.

During the first six days of minoxidil treatment plasma renin activity rose progressively from a mean of $9 \cdot 7 \pm 3 \cdot 1$ to $26 \pm 7 \cdot 2 \mu \mathrm{g} / 1 / \mathrm{h}$ (fig 1). Urinary sodium excretion fell from $133 \pm 26$ to $86 \pm 18 \mathrm{mmol} / 24$ h. Individual peak renin values (mean $30 \cdot 4 \pm 7 \cdot 6 \mu \mathrm{g} / \mathrm{l} / \mathrm{h}$ ) were reached

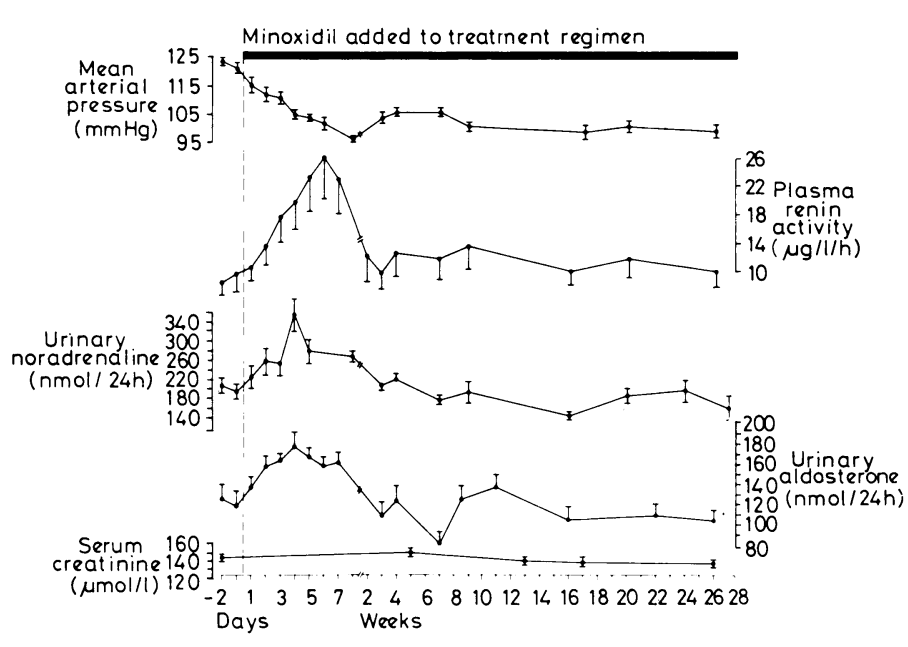

FIG 1 -Changes in mean ( \pm SE of mean) arterial pressure, plasma renin activity, urinary noradrenaline and aldosterone excretion, and serum creatinine concentration after minoxidil (phase 1) in six patients completing study.

Conversion: SI to traditional units-Urinary noradrenaline: $1 \mathrm{nmol} / 24 \mathrm{~h}$ $\approx 0.16 \mu \mathrm{g} / 24 \mathrm{~h}$. Serum creatinine: $1 \mu \mathrm{mol} / 1 \approx 0.01 \mathrm{mg} / 100 \mathrm{ml}$. Urinary aldosterone: $1 \mathrm{nmol} / 24 \mathrm{~h} \approx 0.36 \mu \mathrm{g} / 24 \mathrm{~h}$.

.

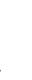


between days 4 and 8 , which corresponded with the maximum increase in dosage to a mean of $10 \pm 2.4 \mathrm{mg} /$ day. During the second and third weeks plasma renin declined to a mean of $10 \pm 2 \cdot 2 \mathrm{~kg} / \mathrm{l} / \mathrm{h}$. This occurred despite slightly larger doses of minoxidil. Renin activity tended to rise again slightly during weeks 3-12, mainly because of concurrent treatment with frusemide. At the end of phase 1 , when frusemide was stopped, renin remained at the pre-minoxidil concentration of $11.5 \pm 3.6: \mathrm{g} / 1 / \mathrm{h}$ and urinary sodium excretion was $137 \pm 21 \mathrm{mmol} 24 \mathrm{~h}$.

No changes in adrenaline excretion occurred during the study, but noradrenaline excretion increased from $207 \pm 29 \cdot 6$ to $355 \pm 33 \cdot 1$ $\mathrm{nmol} / 24 \mathrm{~h}(35 \pm 5$ to $60 \pm 5 \cdot 6 \mathrm{~kg} / 24 \mathrm{~h})$ in the first four days (fig 1). It fell to $207 \pm 11.8 \mathrm{nmol} / 24 \mathrm{~h}(35 \pm 2 \mathrm{~kg} / 24 \mathrm{~h})$ at the end of the second week, and to $148 \pm 17 \cdot 7 \mathrm{nmol} / 24 \mathrm{~h}(25 \pm 3 \mathrm{~kg} / 24 \mathrm{~h})$ at the end of phase 1 .

Urinary aldosterone excretion increased from $119 \pm 22 \cdot 2 \mathrm{nmol} / 24 \mathrm{~h}$ $(43 \pm 8: \mathrm{g} / 24 \mathrm{~h})$ to a peak of $180 \pm 16 \cdot 6 \mathrm{nmol} / 24 \mathrm{~h}(65 \pm 6 \cdot \mathrm{g} / 24 \mathrm{~h})$ by day 4 (fig 1). It then fell to below the starting value in parallel with plasma renin and urinary noradrenaline. At the end of phase 1 the mean excretion of urinary aldosterone was $105 \pm 19.4 \mathrm{nmol} / 24 \mathrm{~h}$ $(38 \pm 7: \mathrm{kg} / 24 \mathrm{~h})$.

Serum creatinine did not change appreciably during the study (fig 1). Mean serum value was $146 \pm 24.8 \mathrm{umol} / 1(1.65 \pm 0.28 \mathrm{mg} / 100 \mathrm{ml})$ at the beginning and $139 \pm 20.3: \mathrm{mol} / 1(1.57 \pm 0.23 \mathrm{mg} / 100 \mathrm{ml})$ at the end of phase 1. Creatinine clearances tended to increase slightly during the study, from $72 \pm 13.6$ to $81 \pm 17.5 \mathrm{ml} / \mathrm{min}$. The difference, however, was not significant $(\mathbf{P}, 0.05)$.

PHASE 2

No major adverse effects occurred during withdrawal of beta-blocking drugs.

Mean arterial pressure increased gradually from $102 \pm 2.5$ to $107 \pm 2 \cdot 8 \mathrm{~mm} \mathrm{Hg}$ with stepped reduction of the dose of beta-blockers (fig 2). Two months after complete withdrawal it averaged $117 \pm 3 \cdot 0$ $\mathrm{mm} \mathrm{Hg}$. Heart rate increased (together with blood pressure) from $65 \pm 2.5$ to $82 \pm 4$ beats $/ \mathrm{min}(\mathrm{P}<0.05)$, and at two months it was $84 \pm 4$ beats $/ \mathrm{min}$. Only one patient developed tachycardia (112 beats min). Body weight increased to $82 \pm 6 \mathrm{~kg}$.

Mean plasma renin activity did not change appreciably during phase 2 . It rose from $11 \cdot 0 \pm 2 \cdot 3$ to $13 \cdot 6 \pm 2 \cdot 5 \mu \mathrm{g} / 1 / \mathrm{h}$ during withdrawal, and at two months was $14.0 \pm 3.0 \mathrm{\mu g} / \mathrm{l} / \mathrm{h}$. Urinary noradrenaline excretion behaved similarly, being initially $148 \pm 24 \cdot 8 \mathrm{nmol} / 24 \mathrm{~h}$ $(25 \pm 4.2 \mu \mathrm{g} 24 \mathrm{~h})$ and at the end $154 \pm 23.0 \mathrm{nmol} / 24 \mathrm{~h}(26 \pm 3.9$ $\mathrm{kg} / 24 \mathrm{~h})$. Urinary aldosterone also remained much the same, initial and final values being $114 \pm 18.0$ and $117 \pm 20.0 \mathrm{nmol} / 24 \mathrm{~h}(41 \pm 6.5$ and

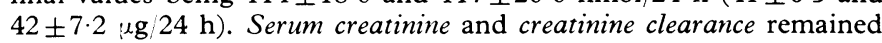
constant during phase 2 .

The overall increase in arterial blood pressure and heart rate was due primarily to three patients. Propranolol, $40 \mathrm{mg} /$ day, decreased their mean arterial pressure from $122 \pm 3$ to $100 \pm 3 \mathrm{~mm} \mathrm{Hg}$ and heart rate from $89 \pm 12$ to $83 \pm 5$ beats/min (fig 2). The six patients were maintained on minoxidil treatment for an average of 15 (range 12-18) months. At the end of this period the average blood pressure was $132 / 89 \pm 4 / 3 \mathrm{~mm} \mathrm{Hg}$.

\section{Discussion}

A potent, non-toxic oral drug is needed for severe hypertension, which cannot be adequately controlled by currently available agents. Minoxidil, a powerful vasodilator effective by mouth, is useful, ${ }^{+}+$but it reflexly increases heart rate and salt and water retention, which counteract its pressure-lowering effect. ${ }^{1}$ Thus high doses of adrenergic blocking agents have been added to prevent tachycardia and diuretics to enhance sodium excretion."

We substituted minoxidil for dihydrallazine in eight patients whose diastolic pressure remained high despite large doses of chlorthalidone, spironolactone, and a beta-blocking drug (table). This induced a prompt, dose-related lowering of blood pressure, which became normal in all patients. When it was first given plasma renin and urinary noradrenaline and aldosterone greatly increased despite beta-blockade but reached baseline values after a further two weeks.

Subsequent stepped reduction and withdrawal of beta-

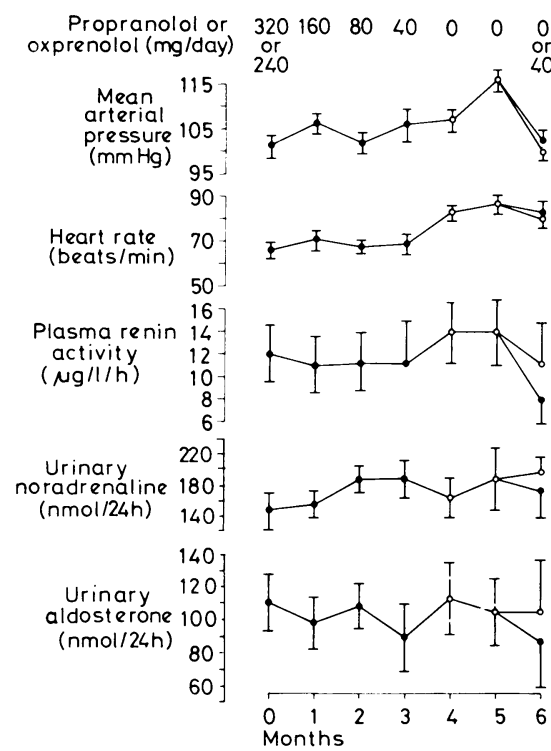

FIG 2-Changes in mean ( \pm SE of mean) arterial pressure, heart rate, plasma renin activity, and urinary noradrenaline and aldosterone excretion during withdrawal of beta-blocking drugs in six patients given minoxidil (phase 2). Closed circles: with beta-blockade. Open circles: without beta-blockade.

Conversion: SI to traditional units-Urinary noradrenaline: $1 \mathrm{nmol} / 24 \mathrm{~h}$ $\approx 0.16 \mu \mathrm{g} / 24 \mathrm{~h}$. Urinary aldosterone: $1 \mathrm{nmol} / 24 \mathrm{~h} \approx 0.36 \mu \mathrm{g} / 24 \mathrm{~h}$.

blockers caused no change in mean arterial pressure and heart rate in three patients and only slight increases in the other three, who responded to small doses of beta-blockers. Surprisingly, no significant changes in plasma renin activity or urinary noradrenaline and aldosterone occurred during withdrawal.

Changes in renin activity did not appear to be causally related to the blood-pressure reduction induced by minoxidil. The early pronounced rise in plasma renin activity may have been secondary to the increase in catecholamines mediated through baroreceptor reflexes. But renin stimulation by catecholamines seems unlikely with doses of beta-blocking agents high enough to produce changes in heart rate. Furthermore, much larger doses of catecholamines are necessary to overcome beta-blockade and stimulate renin release. ${ }^{11}$ Increased renin secretion could also result from a direct effect of minoxidil on renal blood flow: if intrarenal vasodilatation does not parallel the reduction in systemic peripheral resistance, blood-pressure reduction results in decreased renal blood flow, which is a stimulus to renin release. ${ }^{12}$ The subsequent fall in renin activity could then reflect a secondary readjustment of renal perfusion, due perhaps to decreased subendothelial oedema of the renal arterioles made possible by the return of perfusion pressure to normal. The return to baseline of noradrenaline values could be related to resetting of baroreceptor mechanisms or reduction of vascular reactivity.

Although withdrawal did not cause major increases in blood pressure and heart rate, beta-blockers are probably required (possibly in small doses) in the early phase of minoxidil treatment. In some patients they may become unnecessary after prolonged treatment with minoxidil, when renin and noradrenaline have returned to pretreatment values, though this is difficult to predict in individual cases.

Withdrawal of beta-blockers did not result in increased plasma renin activity. Do they perhaps cease to exert a reninsuppressing effect in long-term treatment ? Similar observations have been reported with diuretics that stimulate renin secretion. ${ }^{13}$ These findings suggest that the influence of various drugs on renin secretion and the effect of renin secretion on blood pressure need to be reassessed by long-term studies.

Grant support came in part from the Swiss National Science 
Foundation (grant No 3.2560.74). RKF was supported in part by the Roche Research Foundation for Scientific Collaboration with Switzerland.

Requests for reprints should be addressed to: Dr H R Brunner, Département de Médecine, Centre Hospitalier Universitaire, 1011 Lausanne, Switzerland.

\section{References}

1 Gilmore, E, Weil, J, and Chidsey, C, New England fournal of Medicine $1970,282,521$.

${ }^{2}$ Koch-Weser, J, Archives of Internal Medicine, 1974, 133, 1017.

: Gottlieb, T B, Katz, F H, and Chidsey, C A, Circulation, 1972, 45, 571.

${ }^{4}$ Limas, J L, and Freis, E D, American fournal of Cardiology, 1973, 31, 355.
${ }^{5}$ O'Malley, K, Velasco, M, and MacNay, J L, Fournal of Clinical Investigation, $1975, \mathbf{5 5}, 230$.

${ }^{6}$ Ueda, H, Yagi, S, and Kanko, Y, Archives of Internal Medicine, 1968, 122, 387.

${ }^{7}$ Küchel, O, Annals of Internal Medicine, 1967, 67, 791.

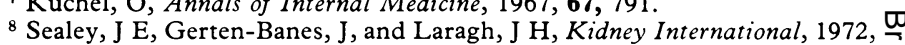
1,240

${ }^{9}$ Sealey, J E et al, Circulation Research, 1972, 31, 367.

10 Crout, J R, in Standard Method of Clinical Chemistry, ed D Seligson, p 62 . New York, Academic Press, 1961.

${ }_{11}$ AssayKeen, T A, et al, Endocrinology, 1970, 87, 1318

${ }_{12}$ Davis, J O, and Freeman, R H, Physiological Reviews, 1976, 56, 1.

${ }^{13}$ Bourgoigne, J J, Catanzaro, F J, and Perry, J M, jun, Circulation, 1968, 乙 37, 27.

(Accepted 30 May 1978)

\title{
Severity of coronary atherosclerosis related to lipoprotein concentration
}

\author{
P J JENKINS， R W HARPER，P J NESTEL
}

British Medical fournal, 1978, 2, 388-391

\section{Summary and conclusions}

The influence of individual lipoproteins on the severity of coronary atherosclerosis was studied in 41 patients undergoing coronary angiography. The extent of atherosclerosis was quantified by a coronary atherosclerosis score (CAS) based on the number and severity of lesions in eight proximal segments of the coronary circulation. The concentration of high-density lipoprotein (HDL) showed a strong inverse association with CAS, which was independent of the effects of age and other lipoproteins. On multivariate analysis concentrations of other lipids-namely, total plasma cholesterol, lowdensity lipoprotein (LDL) cholesterol, and the combined effect of LDL cholesterol plus very-low-density lipoprotein triglyceride-showed direct, significant correlations with CAS, but these were weaker than that of HDL.

This study shows that concentrations of several circulating lipoproteins are related to the severity of coronary atherosclerosis, HDL having an apparent retarding effect. These findings may partly explain the influence of lipoproteins on the development of clinical coronary heart disease.

\section{Introduction}

Recent epidemiological studies have elucidated the importance of individual lipoproteins in predicting future clinical coronary

\footnotetext{
Clinical Research Unit, Alfred Hospital, Melbourne, Victoria 3181, Australia

P J JENKINS, $\mathrm{MB}, \mathrm{BS}$, medical registrar (present address: Liver Unit, King's College Hospital, London SE5 9RS)

Cardiovascular Diagnostic Service, Alfred Hospital, Melbourne R W HARPER, MB, FRACP, cardiologist

Cardiovascular Metabolism and Nutrition Research Unit, Baker Medical Research Institute, Melbourne

$P$ J NESTEL, MD, FRACP, head
}

heart disease. High-density lipoproteins (HDLs) appear to exert the greatest influence independently of other lipo- $\frac{5}{\infty}$ proteins, ${ }^{1-3}$ with low-density lipoproteins (LDLs) having a weaker, though still significant, independent relation with $\vec{\varphi}$ coronary heart disease. ${ }^{12}$ This correlates negatively with HDL $@$ and positively with LDL, so probably HDL retards while LDL accelerates the development of clinical events. While this does not necessarily indicate a similar influence on the progression of $\bar{\partial}$ underlying atherosclerotic disease, the influx and efflux of cholesterol in tissues are closely linked to the metabolism of $\mathbb{\perp}$ LDL and HDL respectively, ${ }^{4-6}$ and therefore the severity of $\overrightarrow{\vec{B}}$ atherosclerosis could be related to these two variables. We $\frac{0}{3}$ attempted to verify this by relating the concentrations of $\vec{\partial}$ circulating plasma lipids and lipoproteins to the extent and severity of coronary atherosclerosis as quantified by angiography.

\section{Patients and methods}

We studied 151 consecutive patients referred to the cardiovascular diagnostic unit at Alfred Hospital for coronary angiographic evaluation of chest pain suggestive of coronary heart disease. One of us (PJN) selected a subgroup of 41 patients ( $28 \mathrm{men}, 13$ women), without knowledge of the clinical history or coronary anatomy, on the basis of plasma lipid concentrations, ensuring that the ranges of ages and lipid profiles resembled those of the whole group. This subgroup therefore included patients with both normal and raised plasma cholesterol and triglyceride concentrations. There was no significant $N$ difference in mean whole-plasma cholesterol and triglyceride concentrations between the entire patient population and the selected subgroup. None of the patients had valvular disease. Table I shows their clinical characteristics.

TABLE I-Clinical data on patients

\begin{tabular}{|c|c|c|}
\hline & $\operatorname{Men}(n=28)$ & Women $(n=13)$ \\
\hline $\begin{array}{l}\text { Mean age in years (range) } \\
\text { No }(\%) \text { with proved myocardial infarction } \\
\text { No }(\%) \text { with risk factors for coronary } \\
\text { disease: } \\
\text { High blood pressure }(>160 / 100) \\
\text { Smoked more than } 10 \text { cigarettes daily } \\
\text { within past } 5 \text { years } . \\
\quad \text { Fasting glucose (concentration above } \\
\quad 6.7 \mathrm{mmol} / 1(120 \mathrm{mg} / 100 \mathrm{ml})) \\
\begin{array}{l}\text { Mean }( \pm \mathrm{SD}) \text { body surface area }\left(\mathrm{m}^{2}\right) \\
\text { Med }\end{array}\end{array}$ & $\begin{array}{l}48 \cdot 8(34-61) \\
16(57) \\
5(18) \\
16(57) \\
2(7) \\
1 \cdot 88 \pm 0 \cdot 14\end{array}$ & $\begin{array}{c}55 \cdot 6(41-65) \\
5(38) \\
3(23) \\
6(46) \\
1(8) \\
1 \cdot 60 \pm 0 \cdot 30\end{array}$ \\
\hline
\end{tabular}

